\title{
Management of Educational Records in Nigerian Universities for Better Results
}

\author{
Chika Josephine Ifedili (Phd) \& Jennifer Jomafuvwe Agbaire (Mrs) \\ Faculty of Education, University of Benin \\ P.O. Box 10073, Ugbowo, Benin City, Edo State, Nigeria \\ E-mail: theifedilis@yahoo.com
}

$\begin{array}{lrr}\text { Received: July 23, } 2011 & \text { Accepted: August 24, } 2011 & \text { Published: December 1, } 2011 \\ \text { doi:10.5539/res.v3n2p52 } & \text { URL: http://dx.doi.org/10.5539/res.v3n2p52 }\end{array}$

\begin{abstract}
The paper investigated the status of record-keeping in Nigerian universities following the general complaints by graduated students, retired staff etc that the record-keeping in Nigerian universities was below standard. The population of the study consisted of all academic and non-academic staff of 114 universities in the six geo-political zones of the federation of Nigeria: North-Central, Northeast, Northwest, Southeast, South-south and Southwest. A sample of 150 academic staff and 150 non-academic staff were selected by stratified random sampling method from each geographical zones of the federation. A total sample of 900 academic staff (485 males and 415 females) and 900 non-academic staff (452 males and 448 females) participated in the study. The data of the study was collected using questionnaire. The questionnaire was titled University Record Keeping Inventory (URKI). The validity of the questionnaire was done by experts in Educational Administration and Planning. The reliability of the instrument was tested using a Split-Half Method. The correlation coefficient was corrected by the use of Spearman Brown Formula. The Pearson Product Moment Correlation was .77 and the final Spearman Brown Formula yielded 0.87. The statistics used were Z-test and simple percentage. The major finding was that record-keeping in Nigerian Universities was below average. Based on the finding, it was recommended that University administrators should train their personnel and update their record-keeping facilities to reflect what is obtainable in global villages.
\end{abstract}

Keywords: Management, Records, Educational, Universities, Nigeria

\section{Introduction}

Every existing organization functions through a flow of information concerning various aspects that make it up facilities, funds, personnel and so on. Records refer to information or data on any such specific subject obtained and preserved for future reference or use. For a piece of information to be considered a record however, it must meet such parameters as genuineness and authenticity (Egwuyenga, 2005). To put it differently, the information must not only be original in its details but also correct and true. Records management on the other hand, involves the effective, efficient and systematic control of the processes of creating, receiving, maintaining, and disposing valuable information about the organization. It is the means of processing information for optimum accessibility and usability, concerned with the origination, collection, organization, storage, retrieval, interpretation, transmission, transformation and use (Vakkari and Cronin, 1992).

Suffice it to say that the planning, coordinating, organizing, controlling and implementing of school activities, particularly tertiary institutions, would be a leap in the dark in the absence of accurate and accessible records that will be made possible through an effective record-keeping practice. Educational records are kept for purposes which range from documenting evidence of every significant activity undertaken in the school system to ensuring a smooth connection between the past, present and future operations of the system, the overall essence of which is to make the right information available to the right person in the right order at the right place and time with the most minimal of costs. There has been series of complaints by lecturers, students, guardians, parents and other educational stakeholders that record-keeping in Nigerian universities is very porous, time-consuming and the records are at times, not available. If the university organization is to perform well, there is need for properly kept records as these will make the management efficient and effective. 
The need for and importance of educational records cannot be overemphasized. Besides the fact that they guarantee continuity in the school system, records contain the information policy makers and educational managers require to make plans and decisions as well as take actions that will facilitate the achievement of stated educational goals and objectives. Records are also used during school inspection exercises with a view to making judgment about the school and providing appropriate recommendations for improvement. Testimonials and academic transcripts of students/graduates often demanded by employees and other higher institutions (in and outside Nigeria) can only be made available through accurate records. Guidance counselors' advise, guide and monitoring of students which are recorded can be used by teachers and school administrators to follow-up on students' progress and identify those in need of remedial classes. Accurate and up-to-date records are required to ensure equity, fair-play and justice both in the award of graduation prizes to students and in the promotion, retirement and replacement of school staff. Moreover, researchers in education who write papers and contribute to knowledge for the improvement of education rely to a large extent on school records for consultation.

In line with the foregoing, Fasasi (2004) holds that school records could enhance managerial duty performances in the areas of planning for resource acquisition and utilization of student and staff personnel services, financial management, improvement of instructional programme, and maintenance of effective interpersonal relationship with the community and external agencies. On a general note, people who make up an institution have the tendency to exhibit more appropriate behavior when they know that records about them are being kept ( Akube, 1991) and this in no small measure, enhances progress and order in the institution.

Given the doubtless significant of educational records, Asogwa (2004) noted that data which arise from the execution of legitimate functions of schools should be properly managed and secured. Unfortunately, this has not been the case in most institutions as Omenyi (1997) observed. According to Afolabi (1991) and Egwuyenga (2009), records management in Nigeria is plagued by such factors as inadequately skilled and experienced management personnel, lack of sufficient funds and the placement of records management in a low priority pedestal in relation to other things. These problems have eaten deep into records management practice in Nigerian universities. In addition, archaic record-keeping methods and technology plus poor data storage facilities can be listed.

While it is a good step to create, correct, genuine and reliable records, it is true as Iwhiwhu (2005) pointed out that creating records without proper provisions for their maintenance can only result in chaos.

\subsection{Statement of the Problem}

Despite the fact that educational records are very vital in the management of educational institutions, it is disheartening to observe that many Nigerian universities do not take record-keeping seriously and most of their essential records are badly stored and secured. As a result, cases of lost or misplaced documents as well as butchered or incomplete files become a common occurrence in these institutions. This is a bane of the Nigerian higher educational system as not only does it impair the smooth, effective and efficient running of the schools but also grossly affects staff and students who often need such records for important purposes.

Undoubtedly, having accurate records is paramount to avoiding a disconnection and ensuring a cohesive continuity in the affairs of any organization, with the inclusion of Nigerian universities.

\subsection{Research Questions}

Based on the above problems, the following research questions are raised to guide the study.

1) Are qualified and skilled personnel employed to keep records in Nigerian universities?

2) Are various methods for storing records in Nigerian universities adequate?

3) Are there continuous updates of these methods to meet new developmental trends?

4) Are all Nigerian universities fully armed with well defined system of record-keeping for complete retrieval and easy channeling so that records are always readily available on demand?

5) Are records properly secured in Nigerian universities?

6) What are the problems of record-keeping in Nigerian universities?

\subsection{Research Hypotheses}

1) There will be no significant difference in the responses of academic and non-academic staff on the status of record-keeping in Nigerian universities.

2) There will be no significant difference in the responses of university staff based on sex on the status of record-keeping. 


\subsection{Significance of the Study}

The study is based on the premise that the management of records in Nigerian universities is not efficient. It is an inquiry into the state of record-keeping in the Nigerian university system with a view to proposing strategies that will make for better record-keeping in the institutions. It is therefore not out of place to expect that the study will be of benefit to the Nigerian government who can be rest assured by the knowledge that not only can Nigerian universities keep good records but also that the government can get hold of the data whenever required.

The university administrations will also benefit as the study will illuminate the stale areas of record-keeping in the universities and also create awareness on how to manage records more effectively with less stress. University staff, students and graduates will not be left out as they will begin to enjoy the blessings of getting required records in their accurate form and within a small space of time. It is hoped that the study will be an invaluable contribution to the only small amount of work that has been done on the lingering issue of university record management and that it will provoke more researches which will largely draw more attention to this important subject.

\section{Methodology}

The research method used was Survey. The population consisted of all academic and non-academic staff of 114 universities in the six geo-political zones of the federation of Nigeria: North-Central, Northeast, Northwest, Southeast, South-south and Southwest. A sample of 150 academic staff and 150 non-academic staff were selected by stratified random sampling method from each geographical zones of the federation. A total sample of 900 academic staff (485 males and 415 females) and 900 non-academic staff (452 males and 448 females) participated in the study.

The data of the study was collected using questionnaire. The questionnaire was titled University Record Keeping Inventory (URKI). It was made up of two parts - Part A was demographic in nature while Part B contained 10 questions bothering on record storing, retrieving, personnel, management etc. The validity of the questionnaire was done by experts in Education Administration and Planning. The reliability of the instrument was tested using a Split-Half Method. The correlation coefficient was corrected by the use of Spearman Brown Formula. The Pearson Product Moment Correlation was .77 and the final Spearman Brown Formula which yielded 0.87. The statistics used were Z-test and simple percentage. The scoring was based on $0-.99$ as poor; 1.00-1.99 below average; while $2.01-3$ good and $3.01-4.0$ excellent.

\section{Results}

Answers to Research Questions are in Table 1.

\section{Testing Hypotheses}

HO1 The first null hypothesis which states that there will be no significant difference in the responses of academic and non-academic staff on the status of record-keeping in Nigerian universities was analyzed using the data collected from the questionnaire and presented as it is on Table 2.

From Table 2, the calculated Z-Value at 0.05 -Confidence Level is 1.90 while the Table Value was 1.96, the null hypothesis that there will be no significant difference in the responses of academic and non-academic staff on the status of record-keeping in Nigerian universities is therefore accepted. Ninety-three percent of academic staff as opposed to $89 \%$ of non-academic agreed that the status of record keeping in Nigerian universities was below average.

HO2 The second null hypothesis which states that there will be no significant difference in the responses of university staff based on sex on the status of record-keeping between government and private universities was analyzed with the data from the questionnaire and the result is on Table 3.

From Table 3, the calculated Z-Value at 0.05 -Confidence Level is 1.73 while the Table Value is 1.96 , the null hypothesis which states that there will be no significant difference in the responses of university staff based on sex is therefore accepted. The mean score for male workers was 1.81 while that of the female workers was 1.77. Both agreed that the status of record-keeping was below average. Although the scores varied, it was however not significant.

\section{Discussions}

From the research analysis, the general consensus from both academic and non-academic workers, both males and females was that the status of record-keeping in Nigerian universities was below average. The records were manned by unqualified and unskilled personnel as indicated by $79 \%$ of the research participants. Eighty-six percent indicated that the record storage was inadequate and this has led to loss of records. The system as it is 
now as agreed by $98 \%$ of the respondents was archaic. There is no defined system of record keeping for complete and easy channeling so that records are always readily available on demand. Some respondents commented on the questionnaire that it would be an understatement to say that it could take up to a month to prepare a student's transcript and in many cases the records were lost.

Record keeping according to all participants had one problem or another. Some of the mentioned problems were storing, retrieving files, files disappearances, illegal removal of pages from records, illegal alteration of records, inexperienced and people with no integrity manning the records, installation of out dated computers, inadequate good computer repairers, public access to records etc. Computer storage commented by some respondents had not helped so much as most of the records were often eaten up by virus. Many records often were lost by fire set by dubious workers who have court cases with the university organizations. In order to get rid of evidence or one can call it "exhibit", at times these individuals set fire on the places where the implicating records are kept, not minding the consequences.

On the question of if there was any difference in record-keeping between the government and private Nigerian universities, $80 \%$ of the research participants agreed that there was. According to them the private universities kept better records than government universities.

\section{Conclusion}

The Nigerian universities being intellectual organizations should be role models in record-keeping to other formal organizations in the economy. University system has a lot to do with records and cannot function well without good record-keeping system. The present situation is quite deplorable. Presently, technology has made it easier to have easier record-keeping. The employment of wrong personnel has made it difficult to achieve the goal. The researchers expected to see well structured record-keeping system manned by trained personnel but the chronic problem of not employing staff based on merit has left a lot to be desired.

\section{Recommendation}

For record-keeping in Nigerian universities to meet the global standard, the following recommendations are made:

- Conferences, workshops and seminars should be organized for all university staff to create more public enlightenment on the importance of good record-keeping.

- The Nigerian Universities should learn to employ workers based on merit. The appointments of wrong workers based on family ties, ethnicism, parochialism, tribalism should be avoided.

- People with integrity should man records.

- Universities should update their record-keeping and their facilities. The out dated computers etc should be replaced.

- Access to records should be limited to the personnel assigned to handle them.

- Records should be stored in different devices so that in case of fire or disappearance of records, one can always produce another one.

- There should be constant anti-virus update. This will prevent the records from being eaten up.

- The use of outside computer repairers should be discouraged. Well trained computer repairers should be employed and should service the computers often. It is also advisable that the universities should send some of their good workers for training.

- Any worker found to aid and abet in destroying records should be relieved of his or her duty or arrested for court action.

- In all universities, it is recommended that a central storage room should be provided in all faculties. All past students' results' booklets should be stored there according to discipline and years of graduation. The same should be done for the retiring staff by Personnel Office.

\section{References}

Afolabi, M. (1991). Education and training archives and records management in Africa. Annual Conference of the Society of Nigeria Archivists, 17, 61-67.

Akube, A. U. (1991). Classroom organization and management: a 5-point strategy. Ibadan Wisdom Publishers Ltd.

Asogwa, G. E. (2004). Library records and maintenance. Journal of Library and Information Science, (2), 88-98. 
Egwunyenga, E. J. (2005). Essentials of school administration. Benin City: Justice Jeco Publishers.

Egwunyenga, E. J. (2009). Record-keeping in universities: associated problems and management options in South-West Geo-political Zone of Nigeria. International Journal of Educational Science, (1), 109-113.

Fasasi, Y. A. (2004). School record keeping: a strategy for management of Nigerian secondary educational institutions. Illorin: Journal of Education, 73-78.

Iwhiwhu, E. B. (2005). Management of records in Nigerian universities: problems and prospects. The Electronic Library, 23(30).

Omenyi, A. S. (1997). Effective records management: a tool for effective counseling in the school systems. Journal of Counselling and Communication, 1 (1), 11-15.

Vakkari, P. and Granin, B. (1992). Conceptions of library and information science: historical, empirical and theoretical perspectives. Proceedings of the international conference held for the $20^{\text {th }}$ Anniversary of the Department of Information Studies, University of Tampere, Finland, 26-28 August, 1991. London: Taylor Abraham.

Table 1. Answers to research questions

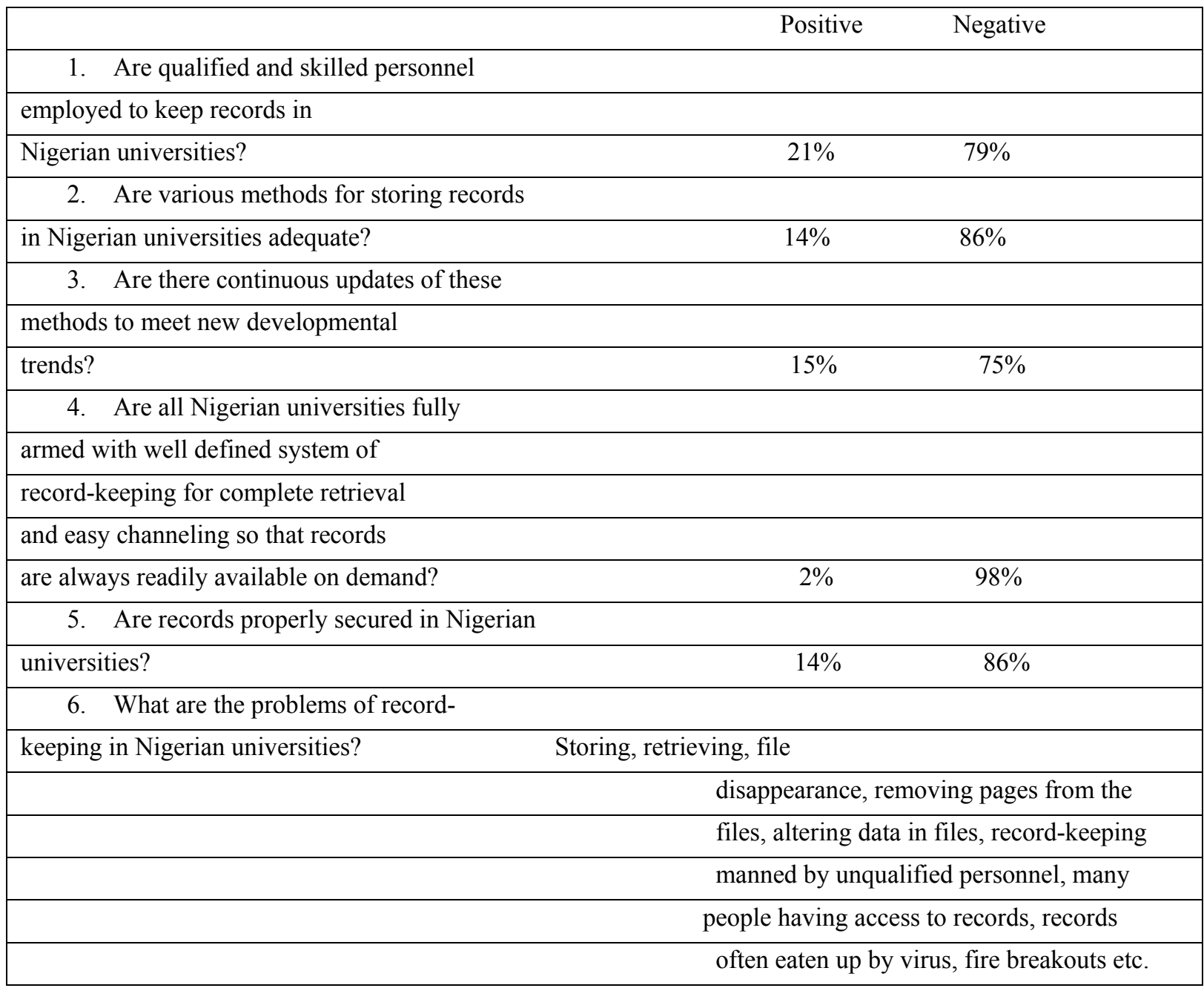


Table 2. Test of significant difference in the responses of academic and non-academic staff on the status of record keeping in Nigerian Universities

\begin{tabular}{|l|l|l|l|l|}
\hline Statistics & academics & Non-academics & Calculated Z-Value & Table Value \\
\hline Number & 900 & 900 & & \\
\hline Mean & 1.85 & 1.89 & 1.90 & 1.96 \\
\hline SD & .45 & .42 & & \\
\hline
\end{tabular}

Table 3. Test of significant difference in the responses of university staff based on sex on the status of record keeping.

\begin{tabular}{|l|l|l|l|l|}
\hline Statistics & Males & Females & Calculated Z-Value & Table Value \\
\hline Number & 937 & 863 & & \\
\hline Mean & 1.81 & 1.77 & 1.73 & 1.96 \\
\hline SD & .45 & .42 & & \\
\hline
\end{tabular}

